\title{
Imagining and Visualizing "Indianness" in Trudeauvian Canada: Joyce Wieland's The Far Shore and True Patriot Love
}

\author{
Kristy A. Holmes
}

Volume 35, numéro 2, 2010

URI : https://id.erudit.org/iderudit/1066792ar

DOI : https://doi.org/10.7202/1066792ar

Aller au sommaire du numéro

Éditeur(s)

UAAC-AAUC (University Art Association of Canada | Association d'art des universités du Canada)

ISSN

0315-9906 (imprimé)

1918-4778 (numérique)

Découvrir la revue

Citer cet article

Holmes, K. A. (2010). Imagining and Visualizing "Indianness" in Trudeauvian Canada: Joyce Wieland's The Far Shore and True Patriot Love. RACAR : Revue d'art canadienne / Canadian Art Review, 35(2), 47-64.

https://doi.org/10.7202/1066792ar

\section{Résumé de l'article}

Cet article propose une étude critique du film The Far Shore (1976) et du livre d'artiste True Patriot Love (1971), tous deux l'oeuvre de l'artiste et réalisatrice canadienne Joyce Wieland, en s'intéressant particulièrement aux façons dont elle a imaginé et visualisé les cultures et les identités autochtones au Canada. Je replace d'abord dans son contexte la construction artistique de l'indianité opérée par Wieland, en rapportant celle-ci aux stratégies suivies par le gouvernement fédéral canadien, sous la direction de Pierre Trudeau, pour redéfinir l'identité autochtone tout au long des années 1960 et au début des années 1970 au moyen de nouvelles politiques sur la citoyenneté et sur l'appartenance culturelle, entre autres par The White Paper on Indian Policy qui fut rédigé en 1969. Une partie des raisons pour lesquelles Wieland a été tentée d'explorer dans son travail le thème de l'indianité pourraient résider selon moi dans le fait que l'identité autochtone était à cette époque une question largement débattue, non seulement au sein du gouvernement fédéral mais aussi dans la plupart des principaux médias canadiens. Enfin, mon examen de l'implication personnelle de Wieland et du soutien qu'elle a apporté à diverses causes politiques autochtones me pousse à affirmer que, même si cette artiste avait une conscience aiguë des traces que laissait l'histoire de la colonisation sur les peuples autochtones, la manière artistique qu'elle a adoptée pour traduire sa solidarité dans son oeuvre n'est pas exempte de préjugés, de stéréotypes ni de constructions colonialistes. Que ce soit dans sa production filmique ou artistique en général, Wieland a eu tendance à idéaliser l'identité autochtone et à positionner les cultures autochtones comme extérieures au monde capitaliste moderne. Il y a entre l'appui personnel qu'elle a apporté aux causes autochtones contemporaines et ce qui ressort de sa production artistique une déconnexion qui s'avère selon moi particulièrement intéressante à étudier.
Tous droits réservés @ C UAAC-AAUC (University Art Association of Canada | Association d'art des universités du Canada), 2010
Ce document est protégé par la loi sur le droit d'auteur. L'utilisation des services d'Érudit (y compris la reproduction) est assujettie à sa politique d'utilisation que vous pouvez consulter en ligne.

https://apropos.erudit.org/fr/usagers/politique-dutilisation/ 


\title{
Imagining and Visualizing "Indianness" in Trudeauvian Canada: Joyce Wieland's The Far Shore and True Patriot Love
}

\author{
Kristy A. Holmes, Lakehead University
}

\section{Résumé}

Cet article propose une étude critique du film The Far Shore (1976) et du livre d'artiste True Patriot Love (197I), tous deux l'œuvre de l'artiste et réalisatrice canadienne Joyce Wieland, en s'intéressant particulièrement aux façons dont elle a imaginé et visualisé les cultures et les identités autochtones au Canada. Je replace d'abord dans son contexte la construction artistique de l'indianité opérée par Wieland, en rapportant celle-ci aux stratégies suivies par le gouvernement fédéral canadien, sous la direction de Pierre Trudeau, pour redéfinir l'identité autochtone tout au long des années 1960 et au début des années 1970 au moyen de nouvelles politiques sur la citoyenneté et sur l'appartenance culturelle, entre autres par The White Paper on Indian Policy qui fut rédigé en 1969. Une partie des raisons pour lesquelles Wieland a été tentée d'explorer dans son travail le thème de l'indianité pourraient résider selon moi dans le fait que l'identité autochtone était à cette époque une question largement débattue, non seulement au sein du gouvernement fédéral mais aussi dans la plupart des principaux médias canadiens. Enfin, mon examen de l'implication personnelle de Wieland et du soutien qu'elle a apporté à diverses causes politiques autochtones me pousse à affirmer que, même si cette artiste avait une conscience aiguë des traces que laissait l'histoire de la colonisation sur les peuples autochtones, la manière artistique qu'elle a adoptée pour traduire sa solidarité dans son oeuvre n'est pas exempte de préjugés, de stéréotypes ni de constructions colonialistes. Que ce soit dans sa production filmique ou artistique en général, Wieland a eu tendance à idéaliser l'identité autochtone et à positionner les cultures autochtones comme extérieures au monde capitaliste moderne. Il y a entre l'appui personnel qu'elle a apporté aux causes autochtones contemporaines et ce qui ressort de sa production artistique une déconnexion qui s'avère selon moi particulièrement intéressante à étudier.

Wrong use of technology has destroyed native peoples. First the crossbow overtook the club and stick. Today a country is taken over through a business deal at [a] conference table. Powerful Canadians sell out the land without thought of its people.

$$
\text { Joyce Wieland }{ }^{1}
$$

Although it could be argued that that much of the interest in native people has evolved out of humanitarian or benevolent concern, I must ask if the intention redeems the results of these endeavours - results such as the entrenching of stereotypes, the continuance of patronage and the representation and objectification of the other.

\section{Marcia Crosby ${ }^{2}$}

In n her essay "Construction of the Imaginary Indian," Haida/ Tsimpsian scholar Marcia Crosby argues that during her formal education in the visual arts she noticed a particular generic construction of "Indianness" permeated the visual imagery of aboriginal peoples and culture in Canadian art. ${ }^{3}$ Such a construction, she argues, is rooted in a narrative of victimization that stresses the idea that aboriginal peoples need to be saved through "colonization and civilization." ${ }^{4}$ Aboriginal peoples are thus no longer "real," but rather "imagined" as a "composite... [which] function[s] as a peripheral but necessary component of Europe's history in North America-the negative space of the 'positive' force of colonialist hegemony."5 In other words, and as Bruce Braun has suggested, art created by the dominant culture using aboriginal subject matter "can be [seen as] complicit with colonial power." 6 Crosby indicates-as quoted in the epigraph above - that the construction of the "imaginary
Indian," whether it is out of benevolence or malevolence, can be understood as a way for the dominant culture to deal with, and ultimately whitewash, the history of colonialism in Canada. Read in conjunction with Crosby's comment, Canadian artist and filmmaker Joyce Wieland's statement suggests that she was sympathetic to the effects that such a history had on aboriginal peoples. This sympathy was translated artistically when she engaged with aspects of aboriginal (namely Inuit) culture, including imagery, songs, poems, and language, and established them as an integral part of her artistic construction of Canadian identity. While Wieland may have been aware of, and sympathetic toward, the historical and contemporary realities of aboriginal peoples in Canada, this does not necessarily mean that her artistic production is free of the expression of colonialist thinking, stereotypes, and constructions.

Positioning Wieland's artistic production in this way draws upon more recent discussions of the ways in which dominantculture artists working in Canada from the late nineteenth century and throughout the twentieth century have visually explored and interpreted aboriginal cultures in ways that ignore and/or sanitize the cultural, political, economic, and social realities of the history of colonization, resulting in works of art that reveal the paternalistic and often racist attitudes of their creators. 7 This critical exploration of Wieland's work can therefore be seen as part of a larger shift within Canadian art-historical scholarship that draws on postcolonial thinking in order to destabilize the nationalist and colonialist underpinnings of disciplinary Canadian art history.

It has been interesting to read and listen to the thoughts and opinions of colleagues in the field of art history and other related disciplines who have heard me speak on this topic, who have read 
drafts of this essay, or who have just had a casual conversation with me. My sense is that there is still some reluctance to position an artist such as Wieland (one that remains so reified, celebrated, and "mummified as mommy" in discourse) within such revisionist scholarship. There is a difference, however, between critically reading Wieland's art production and pronouncing on her as a person. Clearly there is evidence (as I will further discuss) that Wieland was involved in political protests throughout the late 1960s and early 1970s that were in support of aboriginal causes, such as those of the various Cree communities of northern Ontario and Québec who were fighting the federal government and large corporations over land claims and the poisoning of water and fish due to pulp-and-paper mill waste. While this is the case, these are not issues that Wieland overtly visualized or addressed in her artistic production, and it is dangerous to read her work as solely reflective of her personal involvement in protest. Wieland may have been able to recognize some of the contemporary issues that different aboriginal peoples and communities in Canada faced, but I am more concerned with the degree to which this was, or was not, translated artistically. What is most interesting, I want to suggest, is the disconnection between Wieland's own personal involvement in protest and support of contemporary aboriginal causes and what emerges in her artistic production. Therefore, in this essay I argue that while Wieland engages artistically with aspects of aboriginal cultures (and Inuit culture in particular), she predominantly constructs an imaginary concept of "Indianness" that carries a paternalistic attitude replicating colonialist ideas.

I also want to contextualize Wieland's artistic construction of Indianness in relation to the ways in which the Canadian federal government was redefining aboriginal identity throughout the 1960s and early 1970s by way of new policies related to citizenship and cultural belonging, namely, the 1969 White Paper on Indian Policy. ${ }^{8}$ This policy, initiated under the first Liberal government of Pierre Trudeau (1968-79), and presented in the form of a publicly accessible white paper, aroused a fierce and unprecedented response from aboriginal peoples across Canada. ${ }^{9}$ Ideologically couched within the rhetoric of Trudeau's national vision for a modern Canada-the Just Society, The White Paper was the federal government's way of reconceptualizing aboriginal peoples as rights-bearing citizens with the same freedoms and equalities as non-aboriginal Canadians. ${ }^{10}$ Beginning with the attainment of the right to vote in 1960, and continuing in the public debates surrounding The White Paper, the 1960s and early 1970s in Canada witnessed the establishment of aboriginality as both an identity and, for a majority of Canadians, a "problem."

This context is important because it provides a framework for discussion of several of Wieland's works from the early 1970s that depict traditional Inuit stories, songs and language, and the flora and fauna of the Canadian Arctic, as well as her 1976 film, The Far Shore, in which the "imaginary Indian" is an important aspect. Wieland's construction of Indianness is not reliant on the depiction of "real" aboriginal peoples, rather, it is evoked through the use of stereotypical and romanticized signifiers, which are dependent on a conceptualization of aboriginal peoples as existing outside capitalist modernity. The fact that Wieland incorporates aspects of aboriginal cultures in her work at all is, it seems to me, rather unprecedented. There were very few, if any, non-aboriginal artists working in Canada that were creating art that addressed aboriginal issues or visualized aboriginal identities or cultures during the late 1960s and early 1970s. ${ }^{11}$ Part of the reason, I want to suggest, that Wieland may have been attracted to aboriginal cultures is because this was a moment when aboriginality was an identity that was intensely debated not only within the realm of the federal government but also within more mainstream Canadian media.

\section{The Liberal Imagining of "Indianness"}

I want to begin by exploring the ways in which aboriginal identity in Canada was being constructed during the 1960s and early 1970s by new federal government policies, namely The White Paper, in order to demonstrate the connection between these debates and Wieland's personal and artistic interest in the changing conceptualizations of aboriginal identity. As Johanne Sloan and I have both argued, Wieland was an artist who was intensely interested in Canadian nationalism and identity, and the Canadian nation became her primary subject matter in both her works of art and films throughout the late 1960s and early 1970s. ${ }^{12}$ As we have both suggested, her nationalism was not, however, conservative or jingoistic but more in line with New Left nationalism, which concerned itself with the attainment of equality for marginalized groups within Canada, such as women, the working classes, and French Canadians, in addition to striving for political, cultural, social, and economic autonomy from the United States. ${ }^{13}$

Wieland's artistic production from this period often visualizes or references these marginalized groups in various literal and symbolic ways and addresses the importance of Canadian cultural and economic autonomy from the United States. For example, she privileges a voice that speaks to marginalization (such as French Canadian separatist Pierre Vallières in her 1972 film of the same title); she highlights the labour and exploitation of the working classes (such as the workers on strike featured in her 1973 film Solidarity); she fuses mediums such as quilting, embroidery, and knitting with political statements (such as the 1968 quilt emblazoned with Trudeau's governing philosophy, Reason Over Passion); and she stresses the importance of a unified Canada to combat perceived American cultural and eco- 
nomic imperialism (evident in the 1971 quilted work I Love Canada_J'aime Canada, featuring a small embroidered panel that reads "Death to U.S. Technological Imperialism" in English and French). Wieland was an artist who was astutely aware of the ways in which Canada was changing and modernizing, and clearly she observed how marginalized groups, including aboriginal peoples, were being reimagined and rearticulated as equal members of this new "Canadianized" nation-state.

After the passage of the Canadian Citizenship Act in 1947, which established legal recognition of Canadian citizenship, the federal government embarked upon a series of policies and initiatives to assimilate marginalized groups into "mainstream" Canadian society. In their essay "Making Aboriginal People 'Immigrants Too," Heidi Bohaker and Franca Iacovetta discuss the creation of the Department of Citizenship and Immigration (DCI) in 1950, which managed Indian Affairs, immigration, and citizenship until 1966.14 Combining Indian Affairs and immigration into one department was a rather unusual move and demonstrates, as they argue, the ways in which aboriginal peoples were being conceptualized by the federal government as "immigrants too," who needed to be assimilated into mainstream society in a similar way to those born outside of Canada. ${ }^{15}$ As they put it, this new department was formed in order to "deal with two populations perceived by the federal government to be potentially threatening: Ottawa viewed immigrants and status Indians (especially those living on reserves) as marginal and foreign groups who had to be brought into the Canadian mainstream." 16 Bohaker and Iacovetta go on to argue that the DCI promoted "white middle-class society's dominant family ideals, rigid gender codes, and pro-capitalist values," and the programs aimed at aboriginal peoples in particular were "far less respectful" of their cultural values, traditions, and political independence. ${ }^{17}$ Attempts to assimilate aboriginal peoples via various programs administered by the DCI were ineffectual, and by 1966 the department disbanded and Indian Affairs united with Inuit Affairs under the Department of Indian Affairs and Northern Development.

The White Paper on Indian Policy can arguably be seen as the result of a decade of strategies, beginning with the establishment of the DCI, to assimilate the aboriginal population. The policy was introduced in the House of Commons in June 1969, and it followed a year of consultation meetings between the federal government and various aboriginal communities across Canada. These meetings were intended to establish an open dialogue between aboriginal peoples and the government about the best way to revise the Indian Act. The Indian Act, at its most basic level, outlined what could best be described as the shifting and evolving policies of assimilation that the federal government had established since the early nineteenth century. The Indian Act also dictated the relationship between aboriginal peoples and the federal government, and included such things as the system of residential schooling, the reserve system, and the terms by which one could define oneself as Indian. ${ }^{18}$

Under the Liberal government of Lester Pearson, the twovolume Hawthorn Report (1966-67) immediately followed the disbanding of the DCI and was a major investigation into aboriginal standards of living and aboriginal society in general. ${ }^{19}$ The Hawthorn Report drew attention to the extreme poverty, underemployment, unemployment, and high welfare, death, and school dropout rates of aboriginal peoples across Canada. ${ }^{20}$ The report also highlighted the paternalistic and fiduciary relationship between the federal government, particularly the newly formed Department of Indian Affairs and Northern Development (DIAND), and aboriginal peoples. DIAND spent a large percentage of its budget on welfare (39.5\% by $1968-69)$, and initiatives began under Pearson that sought to reduce the dependence of aboriginal peoples on the department's social welfare programs. ${ }^{21}$ By 1967, under increasing criticism from some segments of the public regarding the inability of the government to deal with the "Indian problem," the government decided to revise the Indian Act. 22 When Trudeau was elected in 1968 aboriginal policy was given high priority, and the federal government continued with Pearson's plan to revise the Indian $A c t$, albeit in a profoundly more dramatic and ambitious way. 23

The resulting White Paper argued that in order to reduce the economic gap between aboriginal peoples and the rest of the Canadian population, and for aboriginal peoples to play an active role as citizens in the Just Society, it was necessary for the federal government to repeal the Indian Act in its entirety, transfer the control of reserve land to aboriginal peoples, dissolve DIAND within five years, transfer all remaining aboriginal issues to the provinces, and hire a commissioner to help resolve all land claims and treaties. ${ }^{24}$ The policy was couched in classic liberal ideology and argued that repealing the Indian Act was necessary in order to remove the legislative and constitutional basis of discrimination. By abolishing a piece of legislation that identified aboriginal peoples as special or distinct, the Trudeau government sought to reconceptualize aboriginal peoples as liberal individuals with the same freedoms, equalities, and opportunities as non-aboriginal Canadians. As The White Paper states,

The policy promises all Indian people a new opportunity to expand and develop their identity within the framework of a Canadian society which offers them the rewards and responsibilities of participation, the benefits of involvement and the pride of belonging.... The policy rests upon the fundamental right of Indian people to full and equal participation in the cultural, social, economic and political life in Canada. To argue against this right is to argue for discrimination, isolation and separation. No Canadian should 
be excluded from participation in community life, and none should expect to withdraw and still enjoy the benefits that flow to those who participate. ${ }^{25}$

The White Paper set out to level the playing field with the intent that aboriginal peoples would have a "full role in Canadian society and in the economy while retaining, strengthening and developing an Indian identity which preserves the good things of the past and helps Indian people to prosper and thrive."26

As historian Sally Weaver has argued, The White Paper "mirrored Trudeau's own ahistorical approach to policy-making, and his strong views on the danger and futility of special legislation for cultural groups such as the French Canadians." 27 One of the primary reasons The White Paper was so vehemently attacked was because it was seen as ignoring the history and impact of colonialism and the treaties that had been signed with the federal government regarding, among other things, land claims. Weaver has noted that, after The White Paper was announced, the initial response from the press was generally supportive, viewing its liberal basis as a positive step forward for aboriginal policy, although there was still some hesitation regarding the means by which the government sought to achieve equality. 28 The response from aboriginal communities across Canada was much stronger. Aboriginal leaders, who had flown to Ottawa for the policy's release, immediately held an emergency meeting and released a statement that rejected the new policy, primarily because they had been under the assumption that the Indian Act was going to change rather than be eradicated all together. ${ }^{29}$ An examination of the resistances and contestations that developed in the late 1960s and early 1970s in response to The White Paper reveals the ways in which aboriginal peoples successfully brought issues concerning their identity, and how it was being constructed, to the attention of mainstream Canadian society.

One of the most vehement aboriginal responses came from Harold Cardinal, a Cree from Sucker Creek Reserve and head of the Alberta Indian Association. Cardinal's 1969 book The Unjust Society firmly established him as one of the leading aboriginal activists protesting The White Paper. From the time of its publication, The Unjust Society was seen "as the Indian manifesto of special rights and 'the Indian position' on the White Paper." 30 Dale Turner has noted that "Cardinal's book represented a watershed for Aboriginal intellectuals; their political views could now be published and read within mainstream Canadian society." 31 Cardinal was unapologetically angry towards the federal government, not only for The White Paper, but also for the years of "white man's disinterest, his deliberate trampling of Indian rights and his repeated betrayal of our trust."32 Cardinal calls The White Paper a "programme of extermination through assimilation" and a form of "cultural genocide," and he carefully addresses each point raised in the policy and counters it with a response. 33

One of Cardinal's major grievances with The White Paper was that it did not honour the treaties aboriginal peoples signed with the federal government. He argues that "our treaty rights represent a sacred, honourable agreement between ourselves and the Canadian government that cannot be unilaterally abrogated by the government at the whim of one of its leaders unless that government is prepared to give us back title to our country." $34 \mathrm{He}$, like other aboriginal leaders, was also angry because The White Paper was seen as a policy that was made without the consultation of aboriginal peoples. 35 In response to the repeal of the Indian Act, Cardinal argues that, while the policy is dated and racist, it remains the only form of federal legislation regarding aboriginal rights, treaties, and land claims. As Cardinal writes,

We do not want the Indian Act retained because it is a good piece of legislation. It isn't. It is discriminatory from start to finish. But it is a lever in our hands and an embarrassment to the government, as it should be. No just society and no society with even pretensions to being just can long tolerate such a piece of legislation, but we would rather continue to live in bondage under the inequitable Indian Act than surrender our sacred rights. 36

In June 1970, the Indian Chiefs of Alberta drafted a response to The White Paper entitled "Citizens Plus," often referred to as "The Red Paper," which was quickly endorsed by the National Indian Brotherhood (NIB) and became the official response of the NIB to The White Paper. On 4 June 1970, in a meeting with Trudeau and his cabinet, members of the Alberta Indian Association and the NIB presented "Citizens Plus." This "Red Paper," partly authored by Cardinal, was a firm rejection of The White Paper, especially of the controversial proposal to repeal the Indian Act. "The Red Paper" suggested that the Indian Act should be reviewed and amended rather than "be burned." 37 It also laid out several suggestions for improving the relationship between the federal government and aboriginal peoples, including the appointment of a full-time Minister of Indian Affairs and the acceptance of all treaties as legally binding. 38 In response to the presentation of "The Red Paper," Trudeau admitted that the federal government had perhaps not been "pragmatic enough or understanding enough" in creating the new policy, adding, "We won't force any solution on you, because we are not looking for any particular solution." 39 Throughout the early 1970s, various provincial aboriginal groups presented formal responses to the presentation of The White Paper that condemned it, including a "Brown Paper" from the Union of British Columbia Indian Chiefs, "Wahbung: Our Tomorrows" from the Manitoba Indian Brotherhood, and a position paper 
submitted by the Association of Iroquois and Allied Indians. 40 Forms of aboriginal resistance throughout the late 1960s were to a large degree successful, and in 1970 The White Paper was formally withdrawn.

The overriding criticism of The White Paper was that equality could not be attained for aboriginal peoples without federal recognition of the impact of colonialism, namely in relation to treaties and land claims. Dale Turner has argued that the idea that aboriginal peoples constituted indigenous nations was not part of the "Canadian legal and political imagination" of the late 1960s. 41 Ronald Niezen has suggested further that the categories "indigenous," "native," "aboriginal," and "First Nations" are seen as "[lying] outside the accepted norms of nation-states and the traditions of liberal democracy." 42 This is because such identitarian categories are seen as contradicting the goal of a sovereign, unified nation-state. Indigenism, as a global movement of peoples claiming descent from pre-conquest inhabitants, differs from other civil rights struggles of the 1960s because the goal was not just racial equality, but state recognition of collective rights to nationhood, including self-determination and claims to land. 43

The federal government saw aboriginal peoples as a collective that was different in terms of ethnicity and culture, rather than because of claims to nationhood. Turner argues that, in treating aboriginal peoples as an ethnic collective, The White Paper avoided addressing politically controversial and contentious issues that stemmed directly from Canada's colonial history, including treaty obligations and "the meaning and content of indigenous nationhood within a constitutional framework." ${ }^{4} 4$ To address aboriginal peoples as indigenous nations would mean addressing them as a collective, which, in addition to the French Canadians, would be seen as a threat to the success of Trudeauvian liberalism and federalism. ${ }^{45}$ Turner suggests that to construct aboriginal peoples as liberal individuals, rather than nations, was essentially an easier way for the Trudeau government to deal with the situation. Not only could the federal government lessen its responsibility toward honouring treaties by dissolving DIAND, but it would also be absolved of any political responsibility. 46 In addition, such a strategy would not alter the Trudeauvian vision of Canada, which opposed special or distinct recognition of group identity or multinationalism.

Shortly after the withdrawal of The White Paper, and just less than a year after the October Crisis, on 8 October 1971, Trudeau announced in the House of Commons a new policy entitled "Multiculturalism within a Bilingual Framework." As Himani Bannerji has stated, "Trudeau's gift" of multiculturalism "sidelined the claims of Canada's aboriginal population, which had displayed a propensity toward armed struggles for land claims, as exemplified by the American Indian Movement
(AIM)." 47 The failure of The White Paper can be seen, as Bannerji suggests, as partly responsible for the policy on multiculturalism. In his speech to the House, Trudeau stated,

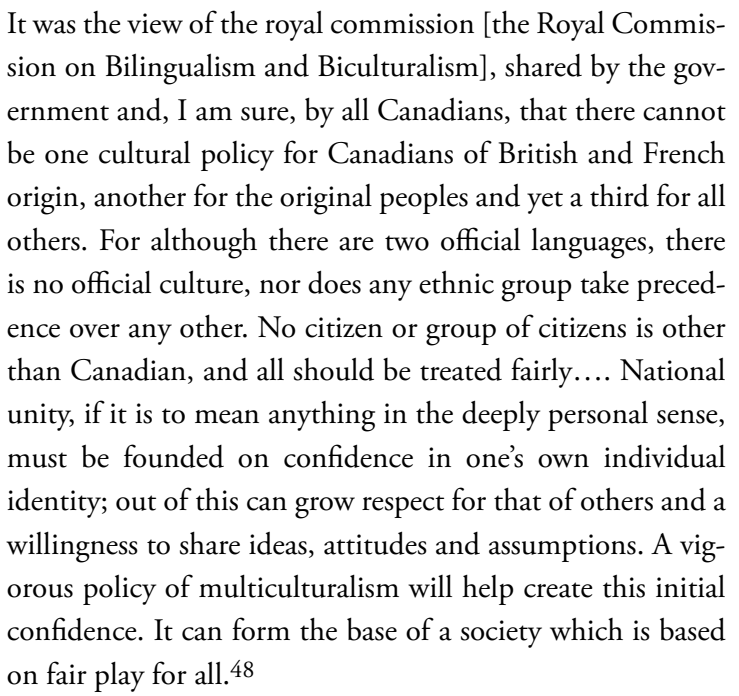
sion on Bilingualism and Biculturalism], shared by the government and, I am sure, by all Canadians, that there cannot be one cultural policy for Canadians of British and French origin, another for the original peoples and yet a third for all others. For although there are two official languages, there is no official culture, nor does any ethnic group take precedence over any other. No citizen or group of citizens is other than Canadian, and all should be treated fairly.... National unity, if it is to mean anything in the deeply personal sense, must be founded on confidence in one's own individual identity; out of this can grow respect for that of others and a willingness to share ideas, attitudes and assumptions. A vigorous policy of multiculturalism will help create this initial confidence. It can form the base of a society which is based on fair play for all. 48

The policy on multiculturalism can be seen as an attempt to manage the diverse and increasingly radical groups within Canada that had been marginalized by the capitalism, colonialism, and patriarchy integral to the liberal nation-state. By proclaiming that Canada had "no official culture" and, in theory, affording no distinct or special status to any particular group, any political agency that might have been ascribed to a group was elided. Trudeauvian multiculturalism thus admitted that difference existed within Canada, but suppressed the social and political subjectivities constituted by that difference. This has led many, among them David Bennett, to dismiss multicultural policy as one of "culturalism":

State-managed multiculturalisms reify and exoticise alterity; addressing ethnic and racial difference as a question of "identity" rather than of history and politics, they translate alterity as cultural diversity, treating difference (a relation) as an intrinsic property of "cultures" and as a value (a socially "enriching" one), to be "represented" as such. 49

Bannerji has levelled a similar criticism, arguing that multiculturalism, as an ideological apparatus of the state, uses cultural categories to suppress social relations, such as class, gender, race, and sexuality, consequently neutralizing their political radicalness. These criticisms of multicultural policy are similar to those raised by Cardinal and others in relation to The White Paper; neither, for example, addressed the history and impact of political realities, namely, colonialism. 


\section{Imagining and Visualizing "Indianness"}

I now want to turn to thinking about the connection between the ways in which aboriginality was being constructed by the federal government throughout the 1960s and Wieland's artistic engagement with aboriginal identity and cultures. Throughout the late 1960s and early 1970s, Wieland consistently drew on her feminist politics and New Leftism in order to create works of art and films that critiqued hegemonic constructions of nationalism, national identity, and citizenship. As Brenda Longfellow has argued, in all of her work Wieland "distinguishes her version of Canada from state versions of the same..., [seeing] her role as one of feminizing national symbols, of subversively aligning her sense of national belonging with emotion, the body, and passion." 50 For the most part I agree with Longfellow, however, when it comes to Wieland's inclusion of aboriginal imagery and cultures in her work, I think her construction of nation becomes more than just one of feminization. When Wieland engages artistically with aboriginal identities, she takes a decidedly more liberal, rather than New Left, position—in short, a more "state version" of nation. This is despite her intentions to use aboriginality as a way of highlighting New Left values such as pacifism, respect for nature and the natural environment, and anti-capitalism. Let me be clear that I am not arguing that Wieland, in any way, supported or endorsed The White Paper's agenda. I am arguing, however, that in the same way The White Paper was criticized as failing to deal with the realities of the history of colonization, so too can aspects of Wieland's work. While Wieland was certainly aware of and sympathetic toward the injustices suffered by aboriginal peoples—and there are aspects of her artistic production that reference contemporary aboriginal issues stemming from colonization-what is most notable about Wieland's engagement with aboriginal identities and cultures is that her construction of Indianness hinges on a more liberal, Trudeauvian positioning.

In what appear to be notes for a speech Wieland made at some point during the early 1970 s, she writes,

Wrong use of technology has destroyed native peoples. First the crossbow overtook the club and stick. Today a country is taken over through a business deal at [a] conference table. Powerful Canadians sell out the land without thought of its people. An area the size of France in Quebec is given by Bourassa to ITT [International Telephone and Telegraph] (one of the most lethal U.S. based multi national corporations). ITT owns this very hotel and paid a million dollars to overthrow Allende's government in Chile. In the face of this we go on as artists creating an indigenous culture. As colonials we are forced to work twice as hard to make the culture. Politically and artistically. We fight for the autonomy of na- ture, and spiritual and economic independence. The Native Peoples only crime was practicing their culture. Until they were destroyed by consumerism. Pipe lines and clearcutting of our once mighty forests. Pulp mills are killing them. Native peoples job is clearly defined. They must support the junk food monopolies and the standard domestic hardware of technology. They are an ancient people. We sophisticated ones have learned to live on arsenic. 51

This is one of the few written documents that reveal Wieland's perspective on aboriginal cultures and some of the contemporary realities facing them. She references, for example, the controversial James Bay hydroelectric and Mackenzie Valley pipeline projects, both of which threatened to displace tens of thousands of Cree, Inuit, and other aboriginal groups in northern Québec, the Yukon, and the Northwest Territories and to wreak devastating effects on the environment.52 In a 1986 interview with Wieland, Barbara Stevenson commented, "You certainly had concerns over the James Bay hydroelectric project when that was in the works," to which Wieland responded, "Did we ever."53 Wieland went on to explain that, while she never directly referred to the project in her art, she helped raise awareness of the Cree's concerns over the project and she contributed to fundraising for the ensuing court cases involving land claims:

We had that night at the St. Lawrence Centre where we all made prints - many artists - and we tried to sell them to pay for the native people's case against you-know-what. No, it was more organizing and trying to support these people [James Bay Cree]. 54

In addition to this statement, Wieland created, what appears to be, a poster advertising the fundraising event at the St. Lawrence Centre for the Arts in Toronto (fig. 1). She includes an image of Chief Billy Diamond, who spoke at the event and who, in 1974, became the Grand Chief of the Grand Council of the Crees of Québec. ${ }^{55}$ At the bottom of the poster Wieland also outlines concerns regarding the environmental consequences of the James Bay project and how it is "a deadly nightmare" for the Cree and Inuit of the region. Beyond a few statements and a poster, we have very little evidence to prove the extent to which Wieland was involved in protesting the James Bay project. In her biography of Wieland, Iris Nowell mentions that Wieland and other artists from Canadian Artists Representation (CAR, the union for artists in Canada) were the ones that organized the event at the St. Lawrence Centre. ${ }^{5}$ She notes that Wieland made a print to sell there, but states that "there is no record of it and no further mention of the work." 57

In her written statement (as cited above), Wieland also refers to the controversy over one of Reed Paper Company's pulp and paper mills in Dryden, Ontario. ${ }^{58}$ This particular mill 
had discharged mercury into the English-Wabigoon river system in northwestern Ontario, polluting the water and fish that the Grassy Narrows First Nation depended on. According to Nowell's biography, Wieland joined the Anti-Reed Campaign, which was formed in response to the Reed Paper Company sponsoring a 1976 exhibition at the Art Gallery of Ontario, entitled Changing Visions-The Canadian Landscape, that featured Wieland's work, along with that of forty other Canadian artists. 59 Wieland and others protested at the opening of the exhibition, but when it opened as planned, she apparently went into the gallery and took her painting of the wall.60

While Wieland's statement alludes to contemporaneous issues involving various aboriginal communities across Canada and the impending displacement of aboriginal peoples generally as a result of capitalist exploitation, she also evokes a romanticized and idealized concept of what it means to be aboriginal. Part of this idealization stems from the way she envisions aboriginal peoples as existing outside capitalist modernity, seeing them as passive victims of technology and modernization whose "only crime was practicing their culture." Her words also suggest that an authentic aboriginal culture had been destroyedimplying the existence of one, monolithic culture-and that aboriginal peoples exist outside historical time as remnants of the past in the present day. While Wieland was sympathetic toward the aboriginal communities that would be affected by the James Bay and Mackenzie Valley projects and the Dryden pulp and paper mill, her statement positions aboriginal peoples as victims without any sort of agency.

Interestingly, Wieland's statement not only evokes a desire to "save" aboriginal cultures, she also identifies herself as aboriginal-like, stating that, as an artist, she is responsible for "creating an indigenous culture" and that she is fighting for the "autonomy of nature, and spiritual and economic independence" in the face of both American and Canadian capitalism. In another part of her notes for her speech, Wieland further states, "The artists conception through art changes society's way of seeing. Therefore the artist is very powerful." 61 Wieland clearly saw her role as an artist as one that expanded beyond a modernist concern with form and aesthetics and her artistic production as contributing to a larger debate over the role that culture could play within the Canadian political imaginary.

Johanne Sloan and I have argued that Wieland sympathized with the situation of women, French Canadians, and the working classes, and it is also clear that she sympathized with the ways in which colonialism and capitalism had affected aboriginal peoples. In notes dated 15 October 1972, Wieland writes,

Since 1967 all of my work has been about Canada, a country which has been largely sold out to the U.S. multi-national corporations, by visible and invisible Canadians, the Amer-

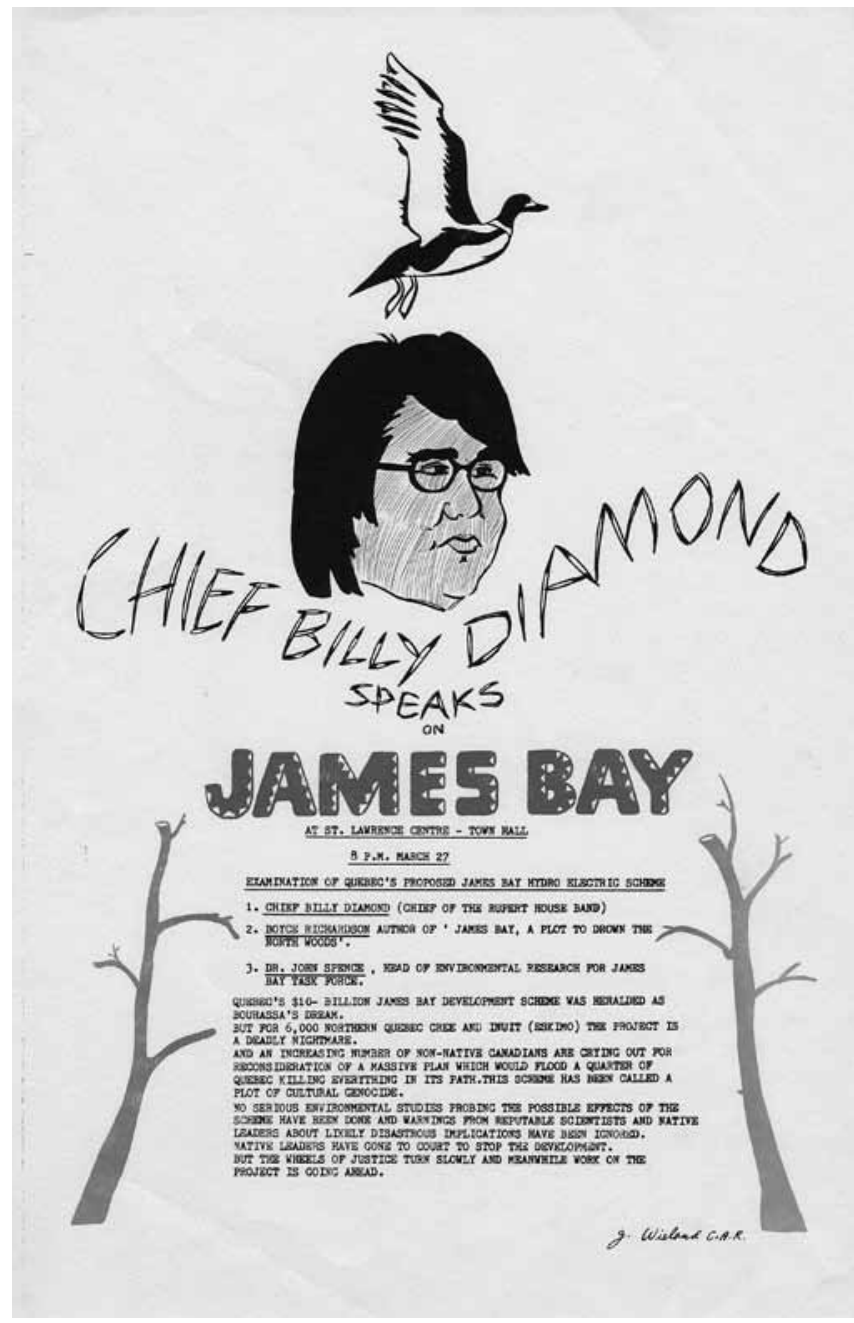

Figure I. Joyce Wieland, Poster Advertising a Lecture by Chief Billy Diamond, ca. 1970-7I. Print on paper. Collection of the National Gallery of Canada, Ottawa (@) National Gallery of Canada (Photo: courtesy of the National Gallery of Canada).

ican power structure determines the future of this country, by exploitation of our minds and resources. They have eternal plans (more damaging than beneficial for us) for power dams, oil, gas, mineral deposits, Indians, Eskimos, redirecting the flow of mighty rivers, the media, and cultural and educational institutions. They would even like to melt the Arctic. 62

Wieland constructs aboriginal peoples within this context as part of the natural environment—as a natural resource—suggesting that they, along with oil, gas, and minerals, will ultimately suffer the most as a result of Canadian and American exploitation of the land. In this sense, her use of the words "Indian" and "Eskimo" do not refer to real people but rather signify a concept of "Indianness" as an identity intimately linked to the natural 


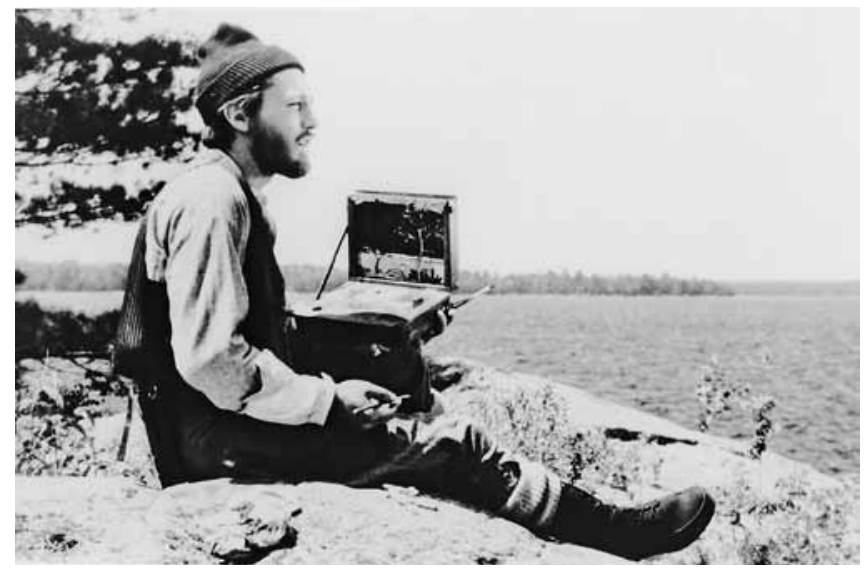

Figure 2. Joyce Wieland, The Far Shore (Tom McLeod), 1976. Film: 106 minutes, colour, sound, $35 \mathrm{~mm}$. (C) Cinémathèque québécoise, Montréal (Film still: Cinémathèque québécoise).

environment. In her artistic production Wieland extends this understanding of aboriginal cultures and identities in order to draw attention to the consequences of exploiting the land for capitalist gain, a strategy that constructs aboriginal peoples as both intimately connected to the natural environment and as victims of capitalist modernity.

Wieland's co-optation of aboriginal cultures and identities to politicize her work is evident in The Far Shore, her 1976 feature-length film. ${ }^{63}$ Wieland imbues one of the main characters, Tom McLeod, with romantic, imagined notions of Indianness in order to warn viewers of ecological damages to the land caused by capitalist exploitation. With a budget of $\$ 435,000$, and financed by the Canadian Film Development Corporation, Famous Players, and Astral Films, The Far Shore was by far Wieland's most ambitious filmic undertaking, and financially and critically her least successful. Wieland had originally titled the project True Patriot Love: A Canadian Love, Technology, Leadership and Art Story and had conceptualized it as early as 1968 as the third part of a trilogy of films dealing with issues of Canadian identity - the other two being Rat Life and Diet in North America (1968) and Reason Over Passion (1967-69).64 Wieland had, in fact, published parts of the original story outline in Film Culture in 1971, and fragments of the original script appear collaged throughout the artist book she created for her 1971 exhibition, True Patriot Love, at the National Gallery of Canada. ${ }^{65}$ In many ways The Far Shore can be seen as a culmination of Wieland's aesthetic, political, social, and cultural concerns of the late 1960s and early 1970s. As she recalled in a 1981 interview, "I felt The Far Shore was pulling together everything I knew so far in life. Really it was what I knew so far about art, but that was what I knew about life-the artist struggling and the life of the artist." 66
Set in Canada in 1919, the film begins with the marriage of the main characters, French Canadian pianist Eulalie de Chicoutimi and English Canadian engineer Ross Turner. After they marry, Eulalie moves from the Québec countryside to Ross's home in Toronto where she becomes increasingly unhappy until she meets the artist Tom McLeod-a character based on the artist Tom Thomson-who resides on the estate. Eulalie and Tom share an unspoken affection for each other, and after Tom refuses to serve as Ross's guide for a silver-mining expedition in northern Ontario, Tom leaves the estate, much to Eulalie's disappointment. During the mining expedition, Eulalie sees Tom and realizes that her loveless, dispassionate marriage to Ross pales in comparison to her feelings for Tom. After taking an axe to Ross's canoe so that he cannot follow her, Eulalie jumps into the lake and swims to meet Tom at his campsite. Ross and his friend and business associate Cluny - this is the only name he is given - search for the pair and, after spotting them, Cluny fires two shots, killing both Eulalie and Tom.

Brenda Longfellow has argued that Wieland's construction of Tom "position[s] him as a surrogate Native, a character who signifies the profoundly romanticized qualities of nativeness:... pacifism, wisdom, and deep ecological and spiritual knowledge of the land." 67 Not only is Tom positioned as a "surrogate Native" but, as Longfellow points out, he is also "the perfect embodiment of melodrama's (and feminism's) recurring fantasy of the feminized man." 68 Longfellow suggests that, while the film empathizes with "Native reverence for the land," an aboriginal voice is "present only in sublimated form through the character of Tom Thomson." ${ }^{6}$ She states that this is not, however, meant as a critique, because Wieland's vision of nation is constructed in "aesthetic and cultural" terms rather than political ones. ${ }^{70} \mathrm{I}$ want to build on Longfellow's analysis of Tom as a "surrogate Native," and I also want to take issue with her claim that Wieland's artistic articulation of nation is more aesthetic and cultural than political—a claim which seems to excuse the problematical way Wieland constructs Tom as aboriginal-like. I would suggest that Wieland constructs Indianness in The Far Shore by suppressing racial and political differences and extolling perceived cultural differences, among them the idea that aboriginal peoples are close to nature, are pacifists, and exist outside capitalist modernity. While racial and political differences are suppressed in the film, it is Wieland's act of suppression that can be read as political - the denial of aboriginal subjectivity as one that has been constituted by colonization is in line with Trudeauvian ideologies.

One of the ways that Wieland conceptualizes the character of Tom as aboriginal-like is by making him an artist and, in particular, by basing his character on the well-known Canadian artist Tom Thomson (fig. 2). In the film, Tom is often shown painting or sketching, and, significantly, he leaves the estate 
in order to paint outdoors full time in northern Ontario. In an interview with Ardele Lister, Wieland noted that the film had "originally sparked from the idea of Tom Thomson."71 She "researched his life for a couple of years," but in the end "had to change his name, and make him just that essence, and call him Tom McLeod."72 There is, I would suggest, a connection between the way that Wieland imbues the "essence" of Tom with creativity, femininity, pacifism, and respect for the land and her own political agenda as an artist. Wieland draws on the popular notion of Thomson as anti-modern: an artist who travelled to remote areas of northern Ontario to paint outdoors in order to capture the so-called essence of Canadian identity on canvas.

Lynda Jessup has argued that the construction of the Canadian artist as anti-modern positions him outside the "constraints of civilization" in the "guise of the prospector, bushwhacker, or woodsman." 73 Wieland alluded to this anti-modern construction of the artist in an interview with Kay Armatage, in which she stated that the character of Tom is "a totally introverted Canadian artist-not completely introverted but you know that kind of loner that goes to the woods." 74 She added that she did not want to "make people escape into bourgeois artists' lives or anything," but was "telling the truth about what went on here [in Canada]."75 The character of Tom is based on this popular conceptualization of the Canadian artist as bushwhacker or woodsman, not, as Wieland said, to fetishize the "bourgeois artist," but, I would argue, because its anti-modern association extols ideas that both Wieland and the character of Tom believe in, among them a society free from the excesses of modernity - urbanization, industrialization, and capitalism. As I will argue, Tom's character becomes a signifier that Wieland uses to warn viewers that these modern excesses will ultimately destroy the nation.

Wieland's construction of Tom as Thomson-like is also connected to the way she imagines the character as Indian. The Far Shore is, however, not the first film to portray Thomson in this way, as Sherrill Grace argues in her text Inventing Tom Thomson. ${ }^{76}$ Other filmic representations of Thomson, such as the CBC's 1977 documentary The Passionate Canadians, also construct him as Indian-like, as Grace points out. ${ }^{77}$ Much of the mythology regarding Thomson-as-Indian stems from the publication of William Little's The Tom Thomson Mystery in 1970. Little's book recounts the true story of a group of artists who thought they had found Thomson's grave in Algonquin Park, and upon having the remains inspected by a coroner, it was reported that they were "either Indian or nearly full breed Indian."78 Wieland highlights Tom's creativity, respect for the land, and anti-capitalism, not only to depict him as an artist, but also to stress these values as those threatened by modernity_values which Wieland perceived as inherent to aboriginal identity and cultures. Wieland explores these ideas by having each of the main characters in the film symbolically represent an identitarian group within Canada-Eulalie represents French Canadians, women, and the working classes, Tom represents aboriginal peoples, and Ross represents English Canadians and, generally, dominant culture. Through the relationships Tom has with Ross and Eulalie, it is evident that he symbolizes the "Indian" and that Wieland uses his character, as well as his relationship with Eulalie, to draw attention to the exploitation of the land for capitalist gain and to warn of the dangers of the hegemonic culture that Ross represents.

The opening scene of the film introduces the two main characters, Ross and Eulalie, and establishes them as signifiers of English Canadianness and French Canadianness, respectively. Eulalie, wearing a peasant-style dress and hat, and singing a song in French, walks through a field of tall grasses and flowers towards Ross, who is wearing a formal suit and surveying the land. Ross gestures to the landscape in the distance and tells Eulalie that soon the land will be greatly improved with the building of a railway and the introduction of other technological advancements, to which Eulalie responds by expressing her love for the landscape and its beauty. Ross proposes to Eulalie during this scene, signifying the impending union of the two in marriage and, with it, the union of English and French Canada. Scenes of Ross and Eulalie's marriage occur during the opening credits, and the film begins when Eulalie arrives in Toronto looking noticeably uncomfortable in her new surroundings. Within the first few scenes of the film, Wieland clearly establishes Ross as Anglophone, capitalist, and masculine, and Eulalie as Francophone, respectful of nature, and feminine.

The characteristics ascribed to Ross and Eulalie are explored further by Wieland in the context of the relationships each have with Tom. The way Wieland introduces Tom into the narrative is important because it establishes a pattern throughout the film that symbolically and ideologically aligns Tom and Eulalie. This pattern is evident in a scene from the beginning of the film when, after Ross gives a speech to his engineering firm, Eulalie suggests that it was perhaps too long, to which Ross angrily snaps, "Just remember one thing my dear, it may seem to you that you're in with a bunch of foreigners, but really you are the foreigner." Wieland then immediately cuts to a close-up shot of Tom's hand drawing a landscape scene and then pans the camera out to reveal a table with vases of flowers and Tom's rustic cabin. Answering a knock on his door, Tom welcomes Ross and Eulalie into his cabin and offers them tea. Ross declines, saying, "Not the kind you drink," adding to Eulalie, "You won't care for it either...filthy stuff." When Tom tells Eulalie it is "Indian bark tea," she accepts. Wieland then cuts to an aerial shot of two teacups and Tom's hands slowly pouring the tea-a gesture not integral to the narrative of the film but significant to the femin- 


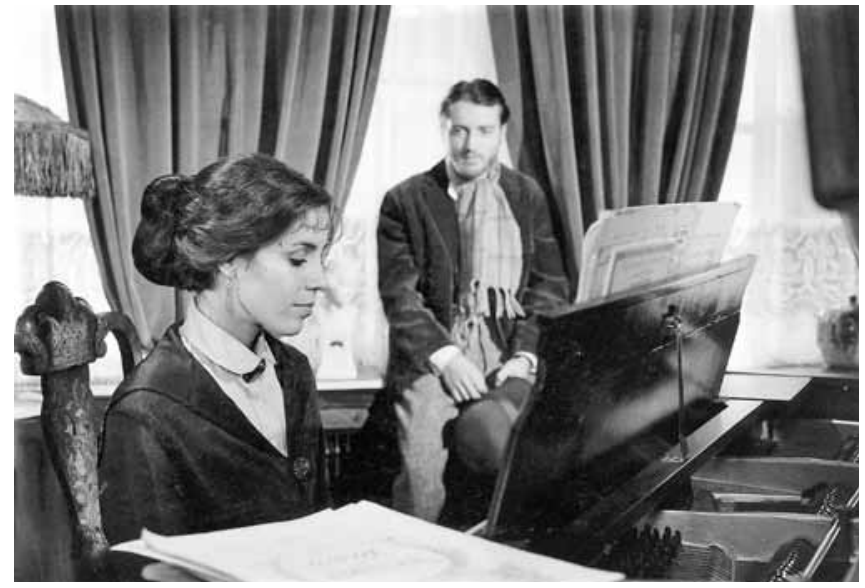

Figure 3. Joyce Wieland, The Far Shore (Eulalie and Tom), 1976. Film: 106 minutes, colour, sound, $35 \mathrm{~mm}$. (C) Cinémathèque québécoise, Montréal (Film still: Cinémathèque québécoise).

ization of Tom and to his identification as Indian-like. This first scene with Tom is important for several reasons: his character enters the film at a moment when the viewer feels sympathy for Eulalie, who has just been alienated by Ross's "foreigner" remark. In addition, Eulalie's acceptance of his Indian tea, despite, and perhaps because of, Ross's rejection of it, is a gesture that indicates to viewers that she has an ally in Tom, beginning an emotional and intimate connection between the two that develops throughout the film.

There are several other scenes in the film that contribute to Tom's characterization as Indian-like. In one scene, for example, Ross, Cluny and Eulalie head home one evening in a car that breaks down on the side of the road. They all walk to Tom's cabin for shelter, and to pass the time, Ross asks Tom to tell a story, saying, "Tell us what the Indians taught you." Cluny interjects, "Here's what the goddamn Indians taught me," taking a large quaff of alcohol from a bottle. With this one line, Wieland effectively disassociates Tom's aboriginality from the contemporary stereotype of the "drunken Indian" and instead reveals him as having a high standard of morality-he is not "that kind of Indian." Tom is also portrayed as lacking the ambition characteristic, in this case, of the capitalist businessman: for example, when he declines Ross's offer to act as a guide for the silvermining expedition, he says, "Ross, you're rich enough, leave the land alone." Cluny then teases him and calls him a pacifist, and a fight breaks out between the two, which ends when Eulalie runs out of the cabin. Throughout the film, Wieland constructs the character of Tom as close to nature and the natural world, reinforcing his Indianness. Tom resides in a rustic log cabin on the estate with his dog, which he treats as though it were human—eating dinner and dancing with it, for example. Ross asks
Tom to lead his silver-mining expedition because he perceives him as having intrinsic knowledge of the land and of where silver could be found.

It is also significant that Wieland vilifies Ross and idealizes the relationship between Eulalie and Tom. Ross points out to Eulalie at the beginning of the film that she is a foreigner and, throughout the film, Wieland depicts Ross (hegemonic Canadian culture) as always struggling to assert authority over Eulalie (French Canada/women/the working classes). Ross's struggle to control Eulalie culminates when he grabs her, tears her clothes off, and rapes her. Symbolically, the rape not only suggests English Canada's desire to control those whom it has marginalized, but it also alludes to the way that Ross, as an engineer, rapes the land of its natural resources and beauty. In the scenes that follow, Eulalie withdraws from Ross and develops a close relationship with Tom, and their union symbolically parallels the oppression of women, aboriginal peoples, and the Québécois by English Canada, technology, capitalism and patriarchy.

In the first of the scenes focusing on the development of Tom and Eulalie's relationship, Tom makes Eulalie dinner, which again associates him with the domestic realm and sets him in direct opposition to Ross, who relies on female domestic labour to run his household. Tom and Eulalie are also aligned in their passion for the arts, which is set in contrast to Ross's profession as an engineer. Tom, for example, enthusiastically listens to Eulalie play the piano and compliments her on her ability, while Ross tells her that the music is distracting him from his work (fig. 3). Another scene features Tom and Eulalie silently mouthing words to each other through a magnifying glass while Wieland focuses the camera on their mouths. In her interview with Kay Armatage, Wieland stated that the reason she made this scene silent was "because it's not for the audience, it's for those two people in the film. But it doesn't matter that we don't know what they say because it's their unspoken love. And I feel that the film has a lot of mystery in it. ${ }^{79}$ Through gestures, rather than spoken language, Wieland connects Tom and Eulalie in an emotional and intimate way.

Throughout the film, viewers feel sympathy for both Tom and Eulalie. Eulalie is emotionally stifled by her abusive and domineering husband and viewers sympathize with her desire to escape the relationship. Ross similarly bullies Tom as he attempts to force him to use his supposed knowledge of the land and natural environment for capitalist gain and, as a result, like Eulalie, Tom ultimately leaves the estate as well. When Eulalie and Tom are finally reunited and after they have consummated their union, they are both killed. In this sense, Tom and Eulalie are seemingly punished for their union, and, with this, the victimization and martyrdom of women, aboriginal peoples, and French Canadians in the hands of English Canadian capitalism, colonialism, and patriarchy is complete. 
The union and deaths of Eulalie and Tom serve as a warning to viewers of what might happen if capitalist exploitation goes unchecked. Ross's desire to build on the land and to strip it of its natural resources ultimately comes at the cost of Tom's and Eulalie's lives. Tom and Eulalie's passionate relationship (made overt in the graphic and lengthy love-making scene in the water) is set in contrast to Eulalie's dispassionate, loveless, and abusive relationship with Ross. It is also significant that Wieland imagines the character of Tom as Indian in order to convey these messages; she highlights New Left ideas of respect for the land and women, pacifism, and anti-capitalism as qualities she perceives as inherent to aboriginal identity and of value to Canadians. Tom consequently becomes a signifier of New Left values in his guise as an imaginary Indian.

Wieland's portrayal of aboriginal peoples as part of the natural environment and her subsequent co-optation of this idea as an expression of her New Leftism are explored further in her non-film work and, in particular, in the artist book she created for her 1971 retrospective at the National Gallery of Canada. Opening on Dominion Day (now Canada Day) in 1971, the exhibition, True Patriot Love / Véritable amour patriotique, like The Far Shore, is arguably the culminating expression of the artistic, political, social, and cultural concerns regarding Canada that Wieland had been cultivating since the mid-1960s. Wieland later told Barbara Stevenson in an interview that the exhibition was a response to her fear that Canada was not going to survive as a nation. 80 "There was a great urgency," she said, "basically in terms: 'Is there going to be a country left?" 81 One of the most important aspects of the exhibition, according to Wieland, was that it highlighted the centrality of the land and its preservation to the nation's survival. As she told exhibition curator Pierre Théberge in an interview conducted on the occasion, "We have to get to the very essential thing now, the land, and how we feel about it." 82 These concerns, I would argue, are mirrored in the book Wieland created in lieu of the standard exhibition catalogue.

Appropriating Bulletin No. 146, Illustrated Flora of the Canadian Arctic Archipelago, which was originally published by the National Museums of Canada in 1964, Wieland transformed this official government document about the flora of the Canadian Arctic by placing images of her works of art, film scripts, dried flowers, photographs of nature, reproductions of Tom Thomson and Group of Seven paintings, and handwritten and typed poems and songs over the actual text of the bulletin, which she then photographed to create the pages of her book. The result is that the pages are photographic reproductions of the collages she created. She described this process in her interview with Barbara Stevenson: "I found the book and it had all the flora of the Arctic and I chose that as my platform from which to build another work. So that the floor or the earth was the book and then I built up things over it and into it." 83 In its entirety, the book visually symbolizes Wieland's version of the Canadian nation, and as a result her conceptualization of aboriginality within the work is significant.

While scholars have critically discussed Wieland's book, little attention has been paid to the ways in which her artistic interventions into the original document form alternative visual narratives involving, in particular, the Inuit of the Canadian Arctic. ${ }^{84}$ While the book as a whole plays with national culture, images, and myths by transforming signifiers of national identity - the Canadian flag and the words of the national anthem, the work of the Group of Seven, and images of the land-the first nineteen pages visually reconceptualize the Canadian Arctic and Inuit culture. The first page of the book features a short passage in Inuktitut collaged over top of a page of the government bulletin. Wieland typed the words to the Inuit song "The Great Sea" in French and English, and set these on the following two pages of the bulletin. On pages four and five, Wieland typed the story of the Great Sea on a piece of paper, which she then placed on a page of the bulletin, juxtaposing it with close-up shots of a 1970-71 wool hooked work, Eskimo Song-The Great Sea, and a newspaper clipping reporting the visit to Sachs Harbour in the Northwest Territories by Jean Chrétien, then Minister of Indian Affairs and Northern Development, and Walter Hickel, the United States Secretary of the Interior (figs. 4 and 5).

From the moment viewers open the book, they are made aware of the Arctic and of its inhabitants in the way that Wieland juxtaposes the government's survey of the land with a passage in Inuktitut - the original bulletin signifies the Arctic/land and the Inuktitut passage signifies the Inuit. On pages four and five, viewers then learn the story "The Great Sea" from a passage taken from a book by early twentieth-century Danish explorer Knud Rasmussen. ${ }^{85}$ "The Great Sea," as told to Rasmussen by Aua of Igloolik, is about Avavnuk who, after becoming filled with a spirit while urinating outside, becomes a shaman and sings a song called "The Great Sea." Wieland includes the words to the song in both Inuktitut and English:

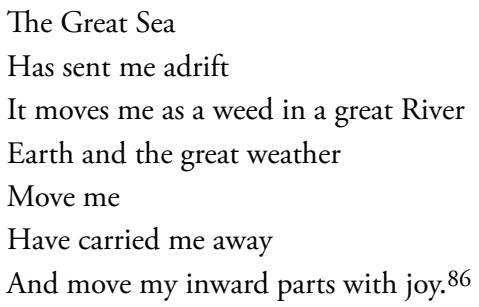

This typed version of the story has been placed on a page of the bulletin, and a photographic reproduction of three pieces of thread extend from the image to the next page, which features a handwritten French translation of the story and a photograph of Wieland's Inuktitut version of her hooked work Eskimo Song- 


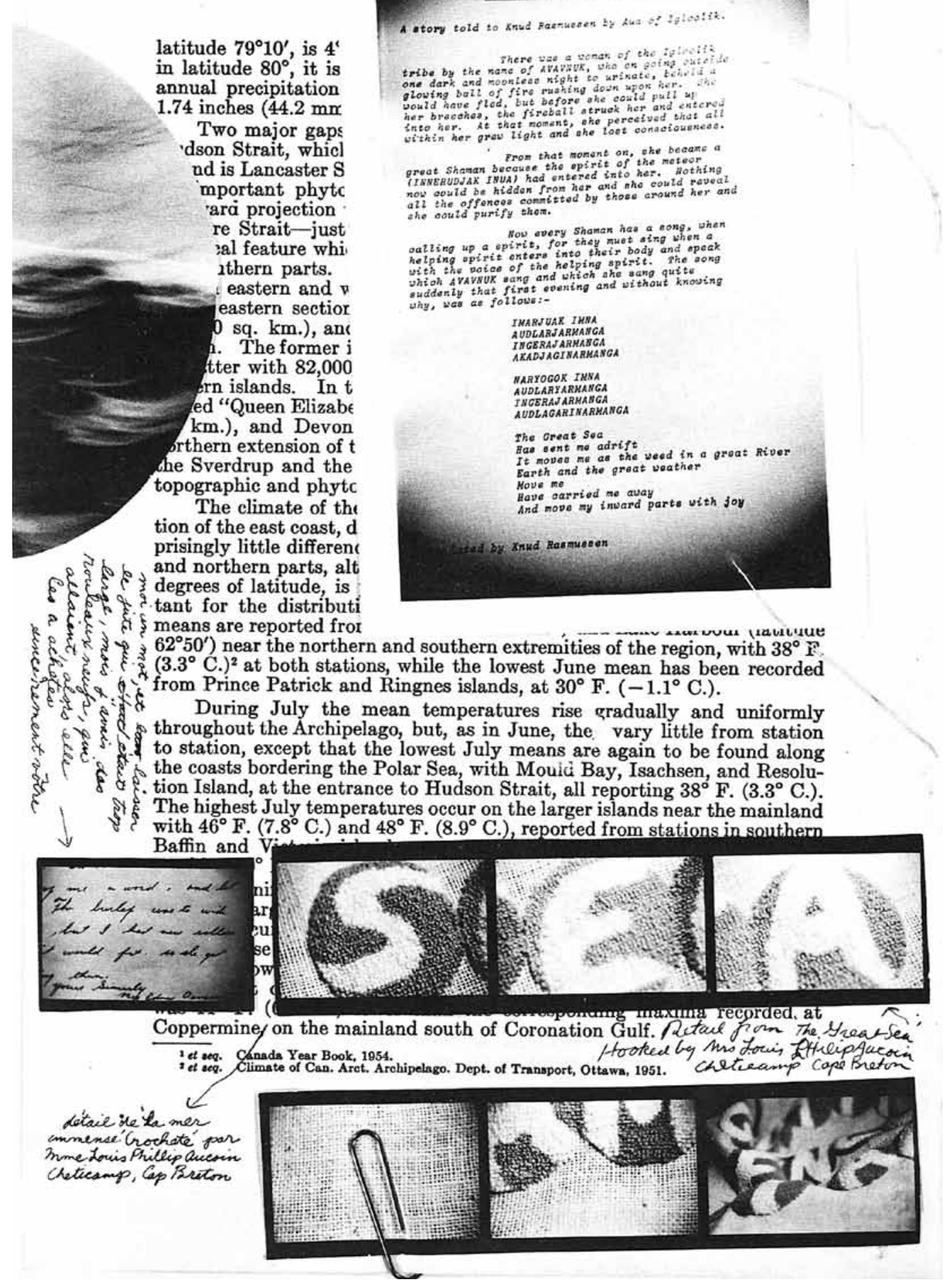

latitude $79^{\circ} 10^{\prime}$, is $4^{\prime}$ in latitude $80^{\circ}$, it is annual precipitation son Strait, whic is Lancaster $\mathrm{S}$ portant phyt re Strait-just sal feature whi thern parts.

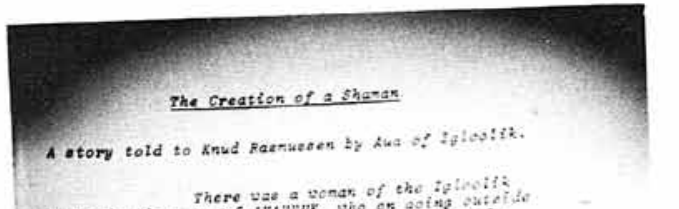

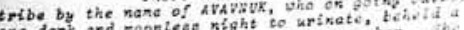
glowing bait of fire pashing doyn wpor hut Sould hase theball atruek her and enten hin her grav light and ahe loot conactounnedo. great Shaman beequee the opirit of the moteop

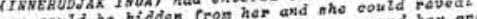
all the offonees connitted by thove arumd her and

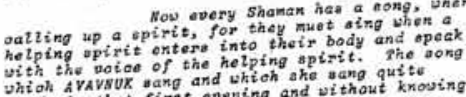

\& o 2 tant for the distribut

है है $\left(3.3^{\circ} \text { C. }\right)^{2}$ at both stations, while the lowest June mean has been recorded from Prince Patrick and Ringnes islands, at $30^{\circ} \mathrm{F} .\left(-1.1^{\circ} \mathrm{C}\right.$. $)$.

During July the mean temperatures rise gradually and uniformly 6. The highest July temperatures occur on the larger islands near the mainland with $46^{\circ} \mathrm{F}$. $\left(7.8^{\circ} \mathrm{C}\right.$.) and $48^{\circ} \mathrm{F}$. $\left(8.9^{\circ} \mathrm{C}\right.$. $)$, reported from stations in southern

Figure 4. Joyce Wieland, True Patriot Love / Véritable amour patriotique (page 4), 197I, $17 \times 25 \mathrm{~cm}$. (Photo: Kristy A. Holmes. () National Gallery of Canada) 


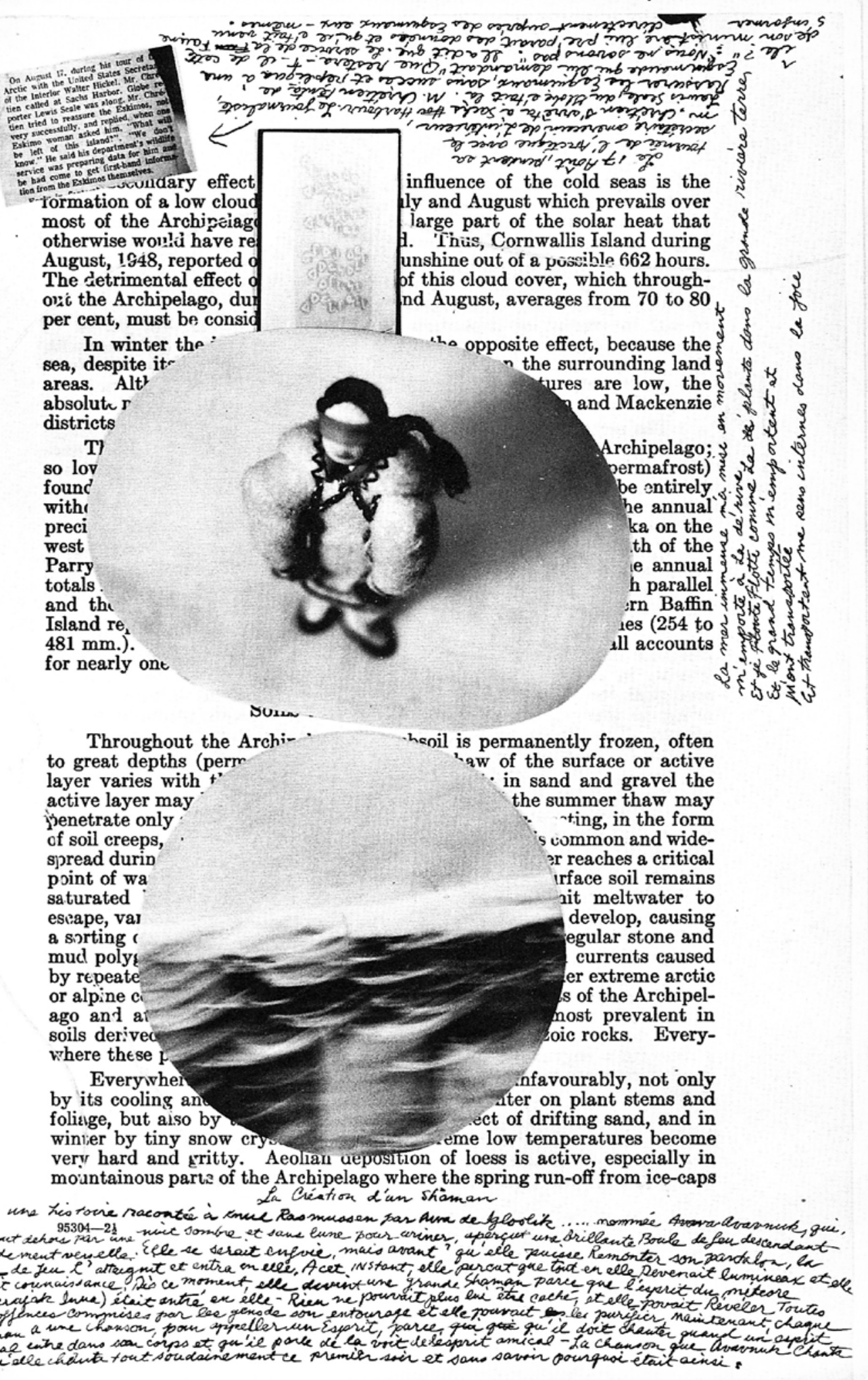

Figure 5. Joyce Wieland, True Patriot Love / Véritable amour patriotique (page 5), 197I, $17 \times 25 \mathrm{~cm}$. 
The Great Sea. The same technique is used in the treatment of the newspaper clipping about Chrétien's visit to Sachs Harbour. Wieland has drawn an arrow from a handwritten, French translation of the clipping to the English newspaper version. In this way she draws viewers' attention to the ways in which she has translated all the written components of her collages into the official languages of Canada, as well as into Inuktitut. Below the typed story "The Great Sea," Wieland has placed details of the English version of Eskimo Song-The Great Sea, which was also featured in the True Patriot Love exhibition.

Wieland's focus on "The Great Sea" is important because she uses the story to politicize her art practice and to construct a concept of herself as aboriginal-like. "The Great Sea" is about an Inuit woman who becomes a shaman and "reveals all the offences committed by those around her [so that] she could purify them." 87 Recalling the importance Wieland placed on the artist's ability to change society's way of seeing, I would argue that she identified with the role of the shaman as one that would allow her to purify the offences of those she perceived as threatening the Arctic and, consequently, its inhabitants. In her 1976 interview with Wieland, Kay Armatage asked her, "What's all this about shamans? Have you done a lot of work on that?" Wieland responded,

In another interview I told the story of an Eskimo woman who happened to go out one night to urinate and as she pulled down her drawers, at that moment a meteor came from the sky and entered into her and from that moment on she was given her song. She was given the power to tell the truth to her people and I made a great quilt from that song. It's called The Great Sea.... I mean if we're not concerned with that, then screw it. It's a religious practice. And I don't even know what I mean by religion even, but I know that there were men and women shamans, and especially in the Arctic, who spoke in tongues and who were in touch with something that we're no longer in touch with. 88

In the interview conducted by Théberge on the occasion of the exhibition, and in response to a question as to whether "Eskimos" had particular significance for Wieland, she replied, "Yeah, because I envy some of the things they had in their past, their ingenuity, creativity, courage and innocence, and no corporate structure." 89 Wieland imagines aboriginality in these statements in a way that romanticizes Inuit society and culture as pre-contact and draws on such anti-modern imaginings to politicize herself, and consequently her art practice, as anticapitalist. Wieland suggests that it is through the production of her artist book and her works of art that certain truths are revealed. In other words, this romanticized notion of Inuit culture as existing outside capitalist modernity is co-opted by Wieland in order to express her New Leftism.
Wieland's imagining of Inuit culture as existing outside capitalist modernity is explored throughout the next several pages of the book. Pages six and seven feature photographs of details of Wieland's large, 1970-71 quilted work Arctic Day, which was also created for True Patriot Love. The work consists of several small circular cushions, each adorned with an image of flora or fauna native to the Canadian Arctic hand-drawn with coloured pencils. Juxtaposed with the close-up images of the quilt are several landscape photographs, pictures of Wieland's hands stitching the quilt, maps of Québec, and photographs of Wieland herself with Théberge. Pages eight and nine feature a photograph of Wieland's hands stitching Arctic Day, which she juxtaposes with a landscape photograph. The situation of her quilted version of the Canadian Arctic, Arctic Day, together with images of her own hands stitching the quilt, on an official government document dealing with Arctic flora, acts to convert a seemingly reasoned categorization of knowledge about Canada's Arctic into an aesthetic and intimate experience. The original text of the document reads, "The present work is intended as a guide or manual to the 340 species and major geographical races of flowering plants and ferns that comprise the vascular flora as it is known at present of the Canadian Arctic Archipelago." 90 The obscuring of the ambitious, comprehensive treatment of the original text by Wieland's interventions challenges the idea that the nation, as documented by a government agency, is capable of being depicted and experienced by reason and rationality alone. Drawing on Arctic flora and fauna and the Inuit constructs an alternative Canadian Arctic to the reasoned and rational one signified in the original bulletin.

The inclusion of a newspaper clipping on page five of the book does suggest, however, that the construction of the Arctic Wieland has presented to viewers is also one that was threatened by capitalist exploitation, although it is not made clear what the specific threat was. The inclusion of this clipping is an example, I would argue, of the complexity of Wieland's constructions of Indianness. On the one hand, you could read the artist book as idealizing and romanticizing the Arctic and the Inuit, and on the other hand, the references to Inuit culture and their presence in the Arctic stress the idea that the North is inhabited not just by flora but by people. The newspaper clipping, in particular, is the one instance where Wieland makes apparent a contemporary political issue involving the Inuit.

The newspaper clipping refers to the tour of the Canadian and American Arctic that Jean Chrétien and Walter Hickel embarked upon in August 1970. Hickel was the former Governor of Alaska (1966-69), and under President Richard Nixon, he became the Secretary of the Interior. Oil and natural gas had been discovered in Alaska in the early twentieth century, but in the late 1960s huge oil reserves had been found and the United States, wanting to capitalize on this discovery, proposed to build 
a pipeline the length of the state in order to transport and distribute the oil. Hickel toured the Arctic with Chrétien in order to get a better sense of how natural resource extraction and management worked by visiting Canadian mining operations, drilling rigs, and testing sites that experimented with building above-ground oil pipelines in permafrost areas. ${ }^{91}$ The newspaper clipping that Wieland includes discusses one of the stops (Sachs Harbour) that Chrétien and Hickel made along their tour and it highlights what appears to be imminent ecological destruction threatening the small community. "Mr. Chrétien tried," it reports, "to reassure the Eskimos, not very successfully, and replied, when one Eskimo woman asked him, "What will be left of this island?' 'We don't know.'"92 Wieland conveys to viewers the potential harm that will befall the Inuit of this particular community by drawing attention to the destruction of both Arctic land and the Inuit by technology and capitalism. While we are not necessarily made aware of what was to happen at Sachs Harbour (perhaps drilling for oil), Wieland was clearly aware of the exploration for oil in the Canadian and American Arctic and wanted to draw viewers' attention to this issue. In the centre of page five is also a photograph of what appears to be an Inuit doll that has been blindfolded. This could be read symbolically and in relation to the newspaper clipping placed just above the image, suggesting that the Inuit are "blind" to the imminent destruction and capitalist exploitation of their land-not out of ignorance, but perhaps because Wieland sees them as powerless to combat the situation.

The narratives that Wieland constructs provoke a sympathetic response from viewers, and position Inuit culture as part of the natural world and as victimized by capitalist modernity. Wieland's quilted, typed, and handwritten versions of "The Great Sea" and her quilted rendering of the Arctic, juxtaposed with the official government survey, co-opt aboriginal culture as a form of resistance to capitalist exploitation. In this co-opting she attempts to salvage a threatened culture-a classical antimodernist strategy — and at the same time to politicize herself and her art production. The Inuit song, poem, and imagery that Wieland collects are presented as remnants of a culture threatened by extinction due to American and Canadian capitalist exploitation. Wieland's act of collecting or salvaging Inuit cultural items can be seen, as James Clifford has suggested, as "reflect[ing] a desire to rescue 'authenticity' out of destructive historical change." 93 Although the idea of rescuing, saving, or salvaging remnants of a culture that appears to be fading or dying out may seem well intentioned, as Virginia Dominguez argues, even the "best liberal intentions do little other than patronize those slated for cultural salvage." 94

In light of the ways in which aboriginality was being defined and discussed in the mainstream media during the late 1960s and early 1970s due to policies such as The White Paper, it is not surprising that Wieland referenced aboriginal cultures in her works of art and films. While she certainly acknowledged aboriginality as an identity, she did so in a way that often idealized and romanticized aboriginal peoples as existing outside capitalist modernity. Positioning aboriginal peoples as largely unaffected by the political, social, and cultural effects of colonization denies the political realities of that history in Canada. While much of Wieland's work of the late 1960s and early 1970s is concerned with negotiating and questioning notions of the Just Society, her engagement with aboriginal identities suggests a certain degree of complicity with Trudeau's vision. Wieland employs a concept of aboriginal identity based on certain notions that stem from stereotypical constructions of aboriginal peoples as close to nature, passive, and existing outside contemporary capitalist society. She co-opts aboriginal identity in her film and visual art as a way of critiquing capitalism, technology, and patriarchy - as an extension of her New Leftism. Her artistic construction of aboriginality thus becomes less about racial, ethnic, and political difference and more about the way that aboriginal cultures are seen and understood by the dominant culture-in other words, her construction is ultimately about rationalizing and reinforcing her own subject position.

\section{Acknowledgements}

I would like to thank David Peerla for reading over a draft of this essay and his helpful suggestions, and the two anonymous reviewers who provided me with critically astute, extremely beneficial, and thought-provoking comments. A note of gratitude also goes to those at the Library and Archives of the National Gallery of Canada, where I undertook some of the research for this essay during my tenure as a Research Fellow in Canadian Art in the summer of 2009-thank you for supporting my research.

Notes

1 Joyce Wieland fonds, Clara Thomas Archives and Special Collections (hereafter CTASC), York University, Toronto, 1999003/005, File 10.

2 Marcia Crosby, "Construction of the Imaginary Indian," in Vancouver Anthology: The Institutional Politics of Art, ed. Stan Douglas (Vancouver, 1991), 287.

3 Crosby, "Construction of the Imaginary Indian," 269.

4 Crosby, "Construction of the Imaginary Indian," 269.

5 Crosby, Construction of the Imaginary Indian," 269. Daniel Francis has also written on the notion of the Imaginary Indian. See Daniel Francis, The Imaginary Indian: The Image of the Indian in Canadian Culture (Vancouver, 1992).

6 Bruce Braun, "BC Seeing/Seeing BC," in The Intemperate Rain- 
forest: Nature, Culture and Power on Canada's West Coast (Minneapolis, 2002), 156.

7 See, for example, Jonathan Bordo, "Jack Pine-Wilderness Sublime or the Erasure of the Aboriginal Presence from the Landscape," Journal of Canadian Studies 27, 4 (Winter 1992): 98-128; Ross D. Cameron, "Tom Thomson, Antimodernism, and the Ideal of Manhood," Journal of the Canadian Historical Association, new series 10 (1999): 185-208; Lynda Jessup, "Prospectors, Bushwhackers, Painters: Antimodernism and the Group of Seven," International Journal of Canadian Studies 17, 1 (Spring 1998): 193-214; Lynda Jessup with Shannon Bagg, eds., On Aboriginal Representation in the Gallery (Hull, 2002); Lynda Jessup, "Landscapes of Sport, Landscapes of Exclusion: The 'Sportsman's Paradise' in Late Nineteenth Century Canadian Painting," Journal of Canadian Studies 40, 1 (Winter 2006): 71-123; Gerta Moray, Unsettling Encounters: First Nations Imagery in the Art of Emily Carr (Vancouver, 2006); Scott Watson, "Race, Wilderness, Territory and the Origins of Modern Canadian Landscape Painting," Semiotext(e) 17 (1994): 96-104.

8 The full and correct title for this policy is Statement of the Government of Canada on Indian Policy (hereafter The White Paper) (Ottawa, 1969).

9 Although it might appear to have racist connotations, the term "white paper" is the name given to a policy in its preliminary stages before it officially becomes legislation. White papers were also meant to be a way for the general public to easily access government policy_part of the federal government's desire for participatory democracy.

10 The Just Society was a national vision for a modern Canada rooted in such liberal notions as equality and the freedom of the individual. See Pierre Trudeau, Memoirs (Toronto, 1993); and Pierre Trudeau and Thomas S. Axworthy, "The Values of a Just Society," in Towards a Just Society: The Trudeau Years, ed. Pierre Trudeau and Thomas S. Axworthy (Markham, Ont., 1990), 357-85.

11 I have not been able to find other non-aboriginal artists working in Canada during the 1960s and early 1970s that visualized aboriginal identities or cultures in their artistic production. I welcome any suggestions you might have.

12 See Kristy A. Holmes-Moss, "Negotiating the Nation: 'Expanding' the Work of Joyce Wieland," Canadian Journal of Film Studies 15, 2 (Fall 2006): 20-43; Kristy A. Holmes, "Negotiating Citizenship: Joyce Wieland's Reason Over Passion," in The Sixties: Passion, Politics, and Style, 42-70, ed. Dimitry Anastakis (Montréal and Kingston, 2008); Kristy A. Holmes, "Joyce Wieland as Cultural Worker: Ecology, Nation and New Leftism in 'True Patriot Love," in Documentary Protocols (1967-1975), 255-68, ed. Vincent Bonin with Michèle Thériault (Montréal, 2010); and Johanne Sloan, "Joyce Wieland at the Border: Nationalism, the New Left, and the Question of Political Art in Canada," Journal of Canadian Art History 26 (2005): 81-104.
13 In using the term New Left, I am referring to the shift that occurred during the 1960s from the more traditional Left, which had been primarily concerned with addressing the exploitation of working class labour, to a Left that was increasingly concerned with the ways that power (colonialism, capitalism, and patriarchy) had created inequalities based on race, gender, sexuality, and class. The New Left in Canada, for example, can be seen as a socialism that was not only concerned with the worker, but also with the liberation of groups perceived as marginalized because of their race, gender, class, or culture. See Ian McKay, Rebels, Reds, Radicals: Rethinking Canada's Left History (Toronto, 2005).

14 Heidi Bohaker and Franca Iacovetta, "Making Aboriginal People 'Immigrants Too': A Comparison of Citizenship Programs for Newcomers and Indigenous Peoples in Postwar Canada, 1940s-1960s," Canadian Historical Review 90, 3 (September 2009): 427-61.

15 Bohaker and Iacovetta, "Making Aboriginal People 'Immigrants Too,"” 428-31.

16 Bohaker and Iacovetta, "Making Aboriginal People 'Immigrants Too," 430.

17 Bohaker and Iacovetta, "Making Aboriginal People 'Immigrants Too," 430.

18 For further discussion of the early development of the Indian Act, see J.R. Miller, Skyscrapers Hide the Heavens: A History of IndianWhite Relations (Toronto, 1991), 99-115.

19 See H.B. Hawthorn, A Survey of the Contemporary Indians of Canada: Economic, Political, Educational Needs and Policies, vol. 1-2 (Ottawa, 1966-67).

20 Sally M. Weaver, Making Canadian Indian Policy: The Hidden Agenda 1968-70 (Toronto, 1981), 20- 27.

21 Weaver, Making Canadian Indian Policy, 25. See Weaver's discussion of these initiatives such as relocation programs, Indian advisory boards, and Indian claims commissions, 24-43.

22 Weaver, Making Canadian Indian Policy, 18-20. The Indian Act defined being an Indian in certain discriminatory ways; if, for example, an aboriginal woman married a non-aboriginal man, she lost her Indian status and consequently her right to live on a reserve and be exempted from taxes. It is also important to note that the Indian Act did not include the Inuit as part of its policy.

23 Weaver, Making Canadian Indian Policy, 59.

24 Weaver, Making Canadian Indian Policy, 166-68; see also The White Paper.

25 The White Paper, 7-8.

26 The White Paper, 8-9.

27 Weaver, Making Canadian Indian Policy, 168.

28 Weaver, Making Canadian Indian Policy, 172-73.

29 Weaver, Making Canadian Indian Policy, 173.

30 Weaver, Making Canadian Indian Policy, 182.

31 Dale Turner, This Is Not A Peace Pipe: Towards a Critical Indigenous Philosophy (Toronto, 2006), 27.

32 Harold Cardinal, The Unjust Society, (Vancouver, 1969/1999), 1. 

Three: Hollow Commitment," 119-27, and "Points Four, Five and Six: Guilt Waived," 128-37.

34 Harold Cardinal, The Unjust Society, 25.

35 Harold Cardinal, The Unjust Society, 108.

36 Harold Cardinal, The Unjust Society, 119.

37 The Indian Chiefs of Alberta, "Citizens Plus," in The Only Good Indian: Essays by Canadian Indians, ed. Waubageshig (Toronto and Chicago, 1970), 16.

38 Waubageshig, The Only Good Indian, 15.

39 Pierre Trudeau, "Statement by the Prime Minister at a Meeting with the Indian Association of Alberta and the National Indian Brotherhood, Ottawa, 4 June 1970," quoted in Weaver, Making Canadian Indian Policy, 185.

40 Weaver, Making Canadian Indian Policy, 188. The responses of various aboriginal associations across Canada to The White Paper were only part of a much larger North American movement during the late 1960s and early 1970s known as Red Power. The Native Alliance for Red Power (NARP), for example, was founded in Vancouver in 1967.

41 Turner, This Is Not a Peace Pipe, 22.

42 Ronald Niezen, The Origins of Indigenism: Human Rights and the Politics of Identity (Berkeley and Los Angeles, 2003), 16.

43 "Indigenous" remains a highly contested category to define and I borrow my definition from Ronald Niezen's brief discussion of it in The Origins of Indigenism, 17-23.

44 Turner, This Is Not a Peace Pipe, 16.

45 In his essay "Quebec and the Constitutional Problem," Trudeau makes it clear that he does not view aboriginal peoples as such a threat: "In terms of realpolitik, French and English are equal in Canada because each of these linguistic groups has the power to break the country. And this power cannot yet be claimed by the Iroquois, the Eskimos, or the Ukrainians." Pierre Trudeau, Federalism and the French Canadians (Toronto, 1968), 31. Trudeau's italics.

46 Turner, This Is Not a Peace Pipe, 24.

47 Himani Bannerji, The Dark Side of the Nation: Essays on Multiculturalism, Nationalism and Gender (Toronto, 2000), 9.

48 Bannerji, The Dark Side of the Nation, 9.

49 David Bennett, ed., Multicultural States: Rethinking Difference and Identity (London and New York, 1998), 4. Bennett's italics.

50 Brenda Longfellow, "Gender, Landscape, and Colonial Allegories in The Far Shore, Loyalties, and Mouvements du désir," in Gendering the Nation: Canadian Women's Cinema, ed. Kay Armatage, Kass Banning, Brenda Longfellow, and Janine Marchessault (Toronto, 1999), 167.

51 Joyce Wieland fonds, CTASC, 1999-003/005, File 10. During the 1960s, under Harold Geneen, ITT (International Telephone and Telegraph) expanded from a telephone/media company to a huge conglomerate corporation. During this period, ITT pur- chased three hundred companies, including the Sheraton hotel chain, which may explain why Wieland refers to ITT owning "this very hotel." See Anthony Sampson, The Sovereign State: The Secret History of ITT (London, 1973); and Robert Sobel, ITT: The Management of Opportunity (New York, 1982).

52 In 1970 Liberal candidate Robert Bourassa was elected premier of Québec and ran on the platform that 100,000 jobs would be created by building one of the largest hydroelectric damns in Canada in the James Bay region of Québec, subsequently displacing 10,000 Inuit and Cree. The Mackenzie Valley pipeline project proposed the installation of a pipeline that would run from Alaska, through the Yukon and the Northwest Territories, and into Alberta. This project would have devastating consequences on the environment and the land that was largely inhabited by Inuit. In both cases, various aboriginal groups took the federal government to court regarding their legal claim to the land. In 1975, in what was seen as a landmark victory for aboriginal land claims, the Inuit and Cree in northern Québec surrendered their rights to the land in return for 150 million dollars to be paid out over fifty years (known as the James Bay and Northern Québec Agreement). The Mackenzie Valley pipeline project was never realized. See Miller, Skyscrapers Hide the Heavens, 252-56.

53 Joyce Wieland fonds, CTASC, 1999-003/005, File 5.

54 Joyce Wieland fonds, CTASC, 1999-003/005, File 5.

55 The Grand Council of the Crees of Québec was formed in 1974 in order to represent and defend Cree interests during the negotiations between the Québec government and the Cree of the James Bay region.

56 Iris Nowell, Joyce Wieland: A Life in Art (Toronto, 2001), 318.

57 Nowell, Joyce Wieland, 346-47.

58 I would like to thank David Peerla for bringing to my attention the controversy over the Reed Paper Company and Grassy Narrows First Nation and Wieland's involvement in the Anti-Reed Campaign.

59 Nowell, Joyce Wieland, 346.

60 Nowell, Joyce Wieland, 347.

61 Joyce Wieland fonds, CTASC, 1999-003/005, File 5.

62 Joyce Wieland fonds, CTASC, 1992-018/007, File 115.

63 For an excellent, and thorough, discussion of The Far Shore, see Johanne Sloan, Joyce Wieland's The Far Shore (Toronto, 2010).

64 Wieland stated in an interview from the early 1970s, "So when Rat Life and Diet was made and Reason Over Passion I can see those as the first two of a trilogy, the third one being True Patriot Love, which eventually got made but it was under a different title.” Joyce Wieland fonds, CTASC, 1991-014/005, VIII, file 75.

65 Joyce Wieland, "True Patriot Love (A Canadian Love, Technology, Leadership and Art Story): A Movie by Joyce Wieland," Film Culture 52 (Spring 1971): 64-73.

66 Lauren Rabinovitz, "An Interview with Joyce Wieland," Afterimage 8, 10 (May 1981): 12. 
67 Longfellow, "Gender, Landscape, and Colonial Allegories," 169.

68 Longfellow, "Gender, Landscape, and Colonial Allegories," 169.

69 Longfellow, "Gender, Landscape, and Colonial Allegories," 171.

70 Longfellow, "Gender, Landscape, and Colonial Allegories," 171.

71 Joyce Wieland fonds, CTASC, 1991-014/005, VIII, 75.

72 Joyce Wieland fonds, CTASC, 1991-014/005, VIII, 75.

73 Lynda Jessup, "Bushwhackers in the Gallery: Antimodernism and the Group of Seven," in Antimodernism and the Artistic Experience, ed. Lynda Jessup (Toronto, 2001), 133.

74 Kay Armatage, "Interview with Joyce Wieland," in Women and Cinema: A Critical Anthology, ed. Karyn Kay and Gerald Peary (New York, 1977), 258.

75 Armatage, "Interview with Joyce Wieland," 260-61.

76 Sherrill Grace, Inventing Tom Thomson: From Biographical Fictions to Fictional Autobiographies (Montréal and Kingston, 2004).

77 Grace, Inventing Tom Thomson, 125.

78 William Little, The Tom Thomson Mystery (Toronto, 1970), 139.

79 Armatage, "Interview with Joyce Wieland," 257.

80 Joyce Wieland fonds, CTASC, 1999-003/005, File 5.

81 Joyce Wieland fonds, CTASC, 1999-003/005, File 5.

82 Pierre Théberge, “Interview with Joyce Wieland," True Patriot Love / Véritable amour patriotique (Ottawa, 1971), n.p.

83 Joyce Wieland fonds, CTASC, 1999-003/005, File 5.

84 See, for example, Christine Conley, "True Patriot Love: Joyce Wieland's Canada," in Art, Nation, and Gender: Ethnic Landscapes, Myths, and Mother-Figures, ed. Tricia Cusack and Sighle Bhreathnach-Lynch (Aldershot, UK, 2003), 95-112.

85 Knud Rasmussen embarked upon a series of expeditions throughout the early twentieth century to the Canadian Arctic, and he wrote and published several books about his travels in addition to translating many Inuit poems, songs, and stories. See Knud Rasmussen, Eskimo Poems from Canada and Greenland (London, UK, 1973).

86 Quoted in Joyce Wieland, True Patriot Love, 3.

87 Wieland, True Patriot Love, 4.

88 Armatage, "Interview with Joyce Wieland," 261.

89 Théberge, "Interview with Joyce Wieland," n.p.

90 Wieland, True Patriot Love, 1.

91 Daniel Nelson, Northern Landscapes: The Struggle for Wilderness Alaska (Washington, 2004), 100.

92 Wieland, True Patriot Love, 5.

93 James Clifford, "Of Other Peoples: Beyond the Salvage Paradigm," in Discussions in Contemporary Culture, ed. Hal Foster (Seattle, 1987), 121.

94 Clifford, "Of Other Peoples," 131. 